\title{
Ser um trabalhador/tornar-se um abacataense: criança, socialização e aprendizagem em uma comunidade quilombola da Amazônia-PA
}

To be a worker/becoming abacataense: child, socialization and learning in a Quilombola community Amazon-PA

Maria Amoras ${ }^{1}$

Maria Angelica Motta-Maués²

Resumo: Este estudo analisa o tornar-se abacataense, visando compreender o significado nativo do trabalho na perspectiva das crianças que crescem na comunidade do Abacatal (PA), o qual é aqui traduzido como suas tarefas obrigatórias e espontâneas, isto é, aquilo que elas definem como ajudas e chamam de (cuidar $d^{\prime}$ ) as minhas coisas, envolvendo obrigação, solidariedade, dever e gosto, ou como as crianças dizem lá: “a criança trabalha ajudando". Apresenta a criança e suas configurações familiares e focaliza aspectos do "ser criança" e da experiência da infância, de modo que seja possível compreender quem são essas crianças, o lugar que ocupam na vida social de Abacatal e como se tornam um trabalhador/um abacataense. Abacatal, que se autodefine como rural e quilombola, localizase na área metropolitana da grande Belém-PA. A análise busca entender os processos de aprendizado e de desenvolvimento infantil através das próprias concepções locais de criança e do crescimento e considera o modo como as crianças intervêm ativamente nesses processos. A família e a organização doméstica são abordadas como espaços de experiências onde as crianças tornam-se trabalhadoras, compreendidas como uma prática de autopoiesis, isto é, de produção de significados sobre o seu mundo. Experiência que também é motivada pelos processos de aprendizagem e socialização no e para o trabalho.

\footnotetext{
${ }^{1}$ Universidade Federal do Pará. E-mail: samoras@ufpa.br.

${ }^{2}$ Universidade Federal do Pará. E-mail: angelicamaues@uol.com.br
}

Latitude, Vol. 10, no 2, pp. 251-285, 2016

DOI: https://doi.org/10.28998/2179-5428.20160205 
Ser um trabalhador/tornar-se um abacataense: criança, socialização e aprendizagem em uma comunidade quilombola da Amazônia-PA

Palavras-chave: Antropologia da Criança; infância quilombola; criança; trabalho; Abacatal-PA

\begin{abstract}
This study analyzes the becoming abacataense, aiming to understand the native meaning of work from the perspective of the children who grow up in the Abacatal community (PA), which is here translated as their mandatory and spontaneous tasks, that is, what they define as cooperation and call (caring of) my stuff, involving obligation, solidarity, duty and delight, or as the kids say there: "the child works by helping". Presents the children and their family configuration, and focuses on aspects of "being a kid" and the experience of childhood, in a way to turn possible the comprehension of who these children are, their place in the social life of Abacatal and how they become a worker/one abacataense. Abacatal, which describes itself as rural and quilombola, located in the metropolitan area of Greater Belém-PA. The analysis aims to understand the learning and child development processes through their own local child and growth conceptions and considers how children are actively involved in these processes. The family and family organization are considered to be spaces of experiences where children become workers, understood as a practice of autopoiesis, that's production of meanings of their world. Experience which is also motivated by learning and socialization processes in and for the work.
\end{abstract}

Keywords: Anthropology of the Child. Quilombola childhood. Child. Work. Abacatal-PA.

\title{
Introdução ${ }^{3}$
}

Este trabalho comunga do argumento de que as crianças são agentes sociais, pois, nesta consideração, as crianças de qualquer grupo social ou cultura, sabem de si, sabem onde estão, o que faz parte da dinâmica de suas

${ }^{3}$ Este artigo é resultado de uma pesquisa maior de doutorado em Antropologia, do PPGSA/UFPA, de autoria da primeira autora, que teve como objetivo discutir a relação criança \& trabalho, tomando as referências teórico-metodológicos da pesquisa sobre e com crianças, na comunidade quilombola de Abacatal-PA, sob orientação da co-autora do artigo. 
vidas; e se confrontam com os princípios de pertença e identidade que lhes são atribuídos. Uma compreensão que nos permite compartilhar a ideia de Costa e Calvão (2010) de que aquelas que participam, solidariamente, de atividades necessárias à vida da coletividade, que se queira assim chamar de "tarefas", estão aprendendo; nesse processo, vão se constituindo (como pessoas, diríamos nós); e é neste sentido, no caso estudado, que estão trabalhando.

São constructos teóricos sinalizadores de que as crianças, historicamente, sempre foram participantes úteis à sociedade (apesar de não serem assim vistas entre nós), pois, qualquer economia dominante precisa da contribuição delas imanente ao sistema, como Qvortrup (2011, p. 326) discute, quando diz: "as crianças são sujeitos ativos e, portanto, estão produtivamente envolvidas no tecido social"; isso, no seu entender, tanto para o envolvimento com as chamadas atividades manuais, como para as mentais.

As formulações das crianças da comunidade quilombola de Abacatal acerca de suas relações com o trabalho justificam a opção de não nos valermos, neste artigo, para compreender as "coisas" das quais elas dizem cuidar, da categoria trabalho infantil, tal como é concebida para balizar os instrumentos metodológicos das pesquisas oficiais. Nesse sentido, a construção do objeto da pesquisa de que resultou este artigo problematizou outras possibilidades de compreensão daquilo que traduzimos como sendo trabalho das crianças em Abacatal. Sem desconsiderar, contudo, a categoria, entendemos, como discute Stropasolas (2012), que a sua ideia motivadora e suas interpretações comprometem a compreensão de "afazeres" singulares dos contextos rurais, caso sejam vistos somente como exploração e alienação.

Isso também significa dizer que as crianças estão concebidas nesta investigação "como ativas na construção e determinação de sua própria vida social, na dos que as rodeiam, e na da sociedade na qual vivem" (SILVA; NUNES, 2002, p. 18), que influenciam e são influenciadas pela cultura, logo, participam da produção desses significados imprimindo-lhes uma dinâmica no seu grupo social, isto é, são atuantes nos processos de socialização e aprendizagem, contribuindo criativamente para o repensar dos esquemas convencionais que envolvem suas experiências com o trabalho por meio de suas atividades obrigatórias e espontâneas. Esse 
Ser um trabalhador/tornar-se um abacataense: criança, socialização e aprendizagem em uma comunidade quilombola da Amazônia-PA

posicionamento, portanto, demarca a defesa da contraposição à idealização e à universalização do par criança-infância.

A metodologia se sustentou nos pressupostos teóricos de uma Antropologia que considera as reflexões contemporâneas para compreender as crianças como agentes (TOREN, 1993, 2002, 2004, 2006, 2010; JAMES; PROUT, 1990; QVORTRUP, 2011; NUNES, 2003; COHN, 2002, 2005;) e para incluí-las como interlocutoras privilegiadas, tanto quanto os adultos (PIRES, 2008, 2010, 2011). Desse modo, o método etnográfico orientou-se pelos postulados teórico-metodológico e político da pesquisa participante para vê-las e ouvi-las, isto é, considerar suas falas sobre os seus universos de vivências e interpretá-las, dando atenção às organizações familiares, aos processos de aprendizado e às suas concepções de criança e infância (PIRES, 2008, 2010, 2011).

A perspectiva apresentada pretende ser uma contribuição a mais à Antropologia no tocante à temática focalizada. Vale ressaltar que, enquanto campo do saber, o campo antropológico ainda tem muito a dizer acerca das crianças de contextos ruralizados e daquelas que vivem a luta pelo reconhecimento do território étnico, como quilombolas, para que representações estereotipadas não continuem a distorcer olhares e impedir que suas esperanças e disposições para a construção da vida sejam respeitadas e consideradas.

\section{Sobre Abacatal}

Abacatal localiza-se na área metropolitana de Belém-PA, no município de Ananindeua, a uma distância de 16 quilômetros da capital. Surgiu na ocupação da Amazônia, nos séculos XVIII e XIX, com a participação de mulheres e homens africanos escravizados e inseridos na organização da agricultura comercial que se ligava diretamente à cidade de Santa Maria de Belém do Grão-Pará (ACEVEDO; CASTRO, 2004). No final de 2014, quando a pesquisa de campo foi encerrada, Abacatal possuía 102 famílias e, aproximadamente, 400 moradores. Dessas 102 famílias, apenas 20 tinham como fonte de renda principal o cultivo da mandioca e a produção de seus derivados (farinha, tucupi e goma de tapioca), vendida na feira do produtor rural, localizada no centro comercial de Ananindeua.

Em média, 30 famílias produziam o carvão vegetal e estavam envolvidas com a plantação e o extrativismo de frutas. As demais, a maioria, atuva em várias atividades - as chamadas pluriatividades - com ou 
sem contratos formais na cidade. São: pedreiros, pintores, ferreiros, marceneiros, eletricistas, montadores de baú para caminhão, plantadores de grama nos condomínios residenciais, carregadores em lojas de eletrodomésticos e de móveis em supermercados, porteiras e porteiros de escolas, operárias e operários em fábricas de reciclagem de lixo e trabalhadoras domésticas. Em média 13 pessoas eram funcionárias e funcionários da escola pública e do posto de saúde da comunidade, todos admitidos por meio de cargos comissionados. No "tempo da política", como dizem para se referir ao período de campanha para cargos eletivos dos poderes legislativo e executivo, também havia mulheres e homens adultos contratados, informalmente, por meio de um pagamento diário irrisório, para "balançar bandeira" na campanha de rua do candidato contratante.

Um dado muito importante presente na vida dos abacataenses é o fato de o indivíduo que possui uma fonte de renda regular, não vive apenas dela. Assim, exercer uma atividade produtiva na cidade, ou um emprego público na comunidade, não significa abandono da agricultura e da coleta na mata nativa; sempre encontram o tempo necessário para essa fonte de renda. Ainda há casos em que numa família, a mulher e o marido trabalham na cidade, mas os filhos ajudam/trabalham com os parentes nas plantações, na feitura do carvão e na coleta. Em todas essas situações as crianças participam das atividades e algumas delas têm produções independentes, como pequenas roças, criação de galinhas e feitura do carvão vegetal. Dentro de Abacatal as crianças comercializam seus produtos na própria rede de parentesco e de vizinhança e participam com sua renda das despesas familiares, além, evidentemente, de a utilizarem para seu uso particular - comprar guloseimas ou algum objeto que desejem, como roupas, sapatos e perfumes.

Os adultos dizem: "o trabalho da cidade e o da prefeitura é hoje, mas pode não ser amanhã e o futuro ninguém sabe", por isso, entendem como uma irresponsabilidade não ensinar, ou não deixar que as crianças aprendam o trabalho rural. E, mais que isso, é o fato de terem clareza de que suas relações se sustentam na colaboração, retribuição e solidariedade, as quais conformam relações de afeto entre pessoas, que incluem certamente a consideração pelo outro, mas também consumo alimentar e segurança pessoal. Logo, não se pode abandonar a terra. É desonroso abandoná-la e, politicamente, enfraquece a luta pelo território. 
Ser um trabalhador/tornar-se um abacataense: criança, socialização e aprendizagem em uma comunidade quilombola da Amazônia-PA

Essas diversas formas de inserção no trabalho demonstram que os abacataenses não formam um grupo social homogêneo, mas a relação entre terra e trabalho, natureza e trabalho, e o modo como essa relação tem sido construída ao longo de tempos, possibilita a conservação de certos aspectos de suas feições rurais e a proteção do território, apesar de estarem a $7 \mathrm{~km}$ da área urbana e fazendo, diariamente, inserções e interações com "os de fora". A vida dos abacataenses, pautada nesse movimento dinâmico entre campo/cidade, muito tem a dizer sobre o modo como vêm engendrando as chamadas "novas ruralidades", trazendo o questionamento "da figura emblemática do trabalhador rural - o agricultor - na representação do campo no imaginário dos pesquisadores e também dos habitantes da cidade e dos neorrurais" (CARNEIRO, 2012, p. 26). Sendo este, um dado muito significativo para o rompimento da imagem hegemônica do trabalhador rural e do rural como espaço da tradição e impermeável à mudança e, ainda, para o reconhecimento, no chamado mundo rural e nas comunidades quilombolas, de uma dinâmica expressa nessa diversidade de atores sociais.

Abacatal, assim como no passado, padece com as ausências do poder público, agravadas pelas novas demandas, quais sejam: a exclusão no sistema econômico; o descaso com as políticas básicas de agricultura, saúde, educação, transporte e saneamento; os frequentes conflitos oriundos da confluência entre o rural e o urbano; o forte apelo ao consumo direcionado aos mais jovens e a discriminação decorrida das marcas históricas de extrema exploração do trabalho, considerado "pelos de fora" como algo que os encerra em um lugar inferiorizado. Apesar disso, mantém fortes ligações com a terra sob um movimento de territorialidade, dinamizado pelo processo de reorganização das referências e das perspectivas identitárias, marcado por eventos significativos de uma luta que muito tem a dizer sobre o significado do trabalho nesse lugar.

Os abacataenses não são mais vistos como rurais pelos "de fora", no caso, os moradores da cidade. Não ser mais visto como rural significa que esse olhar se produz pelas percepções naturalizadas do campo, justificadas pela extrema proximidade dos abacataenses com o espaço urbano. Essa linha tênue entre urbano/rural também tem sido veiculada como desencadeadora do aumento da pobreza e da perda dos valores que fortalecem laços comunitários em lugares com essas características, sendo 
uma visão hegemônica sobre a ruralidade: um lugar de pessoas vulneráveis às imposições da cidade (CARNEIRO, 2012).

A discussão apresentada à temática, formulada a partir do olhar dos abacataenses sobre si e daqueles que vivem na cidade sobre Abacatal, sustenta-se na ideia de que as sociedades são dinâmicas e diversas, como também são grupos e pessoas. E, nesse movimento, pessoas e grupos se modificam em diferentes aspectos, a começar pelas formas de produção no decorrer dos tempos. Nesse sentido, compreendemos que o trabalho das crianças, ou aquilo que elas fazem, ou como está formulado em Abacatal e chamado pelas crianças - o (cuidar d') as minhas coisas (que envolve obrigação, dever, espontaneidade e gosto ${ }^{4}$ ) e que significa ajudar, ou como as pessoas dizem lá: "a criança trabalha ajudando", ação realizada no âmbito doméstico, nas redes de parentesco e de vizinhança e na escola - pode existir de diversas formas, produzindo significados e escolhas.

Então, o escopo empreendido movimentou a pergunta inicial: como os abacataenses tornam-setrabalhadores? $\mathrm{O}$ que implica, ser ou ter a identificação que, junto com a primeira, define essas pessoas, de abacataense. Para tanto, foi preciso acompanhar, detalhadamente, do ponto de vista individual e diacrônico, o processo que culmina na autoidentificação pessoal do trabalhador, categoria autorreferente dos abacataenses, considerando as implicações de escolhas de identidades frente ao mundo moral, como discute Cardoso de Oliveira (2002; 2006).

Assim sendo, sob o olhar orientado pela noção de "estrutura performativa" desenvolvida por Sahlins (1990), em sua antropologia histórica $^{5}$ e pela ideia de autopoiesis ${ }^{6}$, construída por Toren (2004), o

4 Essas atividades se apresentam em Abacatal tal como reflete Certeau (2011, p. 47): “Obrigado" não se apresenta no sentido repressivo, mas enquanto "isso o obriga", cria obrigações, etimologicamente laços/vínculos.

5 Para Sahlins (1990): As "estruturas performativas" emergem das relações e práticas dos sujeitos em situações históricas concretas, e produzem inovações e mudanças.

6 Segundo Toren (2010, p. 20), "Para entender a natureza social da autopoiesis humana [autopoeiéticos- autocriadores, autoprodutores] é preciso que analisemos como as condições do mundo são vividas por pessoas de todas as idades, e também o que as crianças fazem especificamente dessas condições - isto é, as ideias que as crianças constituem ao longo do tempo, como elas descrevem e compreendem o mundo". 
Ser um trabalhador/tornar-se um abacataense: criança, socialização e aprendizagem em uma comunidade quilombola da Amazônia-PA

trabalho buscou interpretar a teia de relações que envolve o trabalho em Abacatal, para compreender, isto é, interpretar do ponto de vista antropológico, significados da relação criança $\mathcal{E}$ trabalho nesse lugar, atentando especialmente ao modo como elas - as crianças - são agentes da construção desses significados.

Compreender como o trabalho é incorporado pelas crianças e mostrar como as diferenças, na percepção e na relação com o trabalho, segundo as diferentes faixas etárias infantis, revelam o processo pelo qual uma pessoa se torna adulta em termos de ser uma "pessoa trabalhadora". Sendo possível vislumbrar como se dá o processo de transformação das ideias sobre o trabalho no cotidiano infantil, em direção à constituição do trabalhador adulto. Para isso, é problematizada a categoria ajuda para investir na tentativa de compreender o envolvimento efetivo dessas crianças nas atividades solidárias e produtivas, as quais evidenciam diferenças e similitudes entre o trabalho das crianças e o trabalho dos adultos.

\section{As expectativas familiares para o nascimento de uma criança abacataense}

Durante o trabalho de campo, no período de 2009 a 2014, as mulheres sempre se mostravam desejosas em gerar um filho. Uma mulher casada chorou copiosamente porque, pela segunda vez, perdera mais um filho devido à ocorrência de abortos espontâneos. Esse filho estava sendo muito desejado, mesmo sabendo, como ela mesma comentou, entre um suspiro e outro, que eu e meu marido tamo desempregado ${ }^{7}$.

Durante uma ação da Secretaria Municipal de Saúde do Município, uma mulher casada e de semblante tristonho olhava para três irmãs ainda bem novas e solteiras, de 15, 16 e 17 anos: a de 15 e a de 16 anos estavam com seus nenéns recém-nascidos ao colo e a de 17, grávida de nove meses, aguardava os sinais do parto; a menina de 14 e a de 17 anos engravidaram

$7 \quad$ Esse casal foi assim constituído: A mulher, nascida em uma das famílias tronco que deu origem a Abacatal, trabalhava de doméstica na cidade e o homem, nascido em outro município, trabalhava de pedreiro, no setor da construção civil na cidade, antes do segundo aborto. 
de homens "de fora" 8 e casados; e, a de 15, dizia que o pai de seu filho era um rapaz "de dentro", mas que não reconhecia a paternidade". A tristeza da mulher transparecia como se lamentasse o fato de possuir as condições desejadas para se ter um filho atualmente em Abacatal, mas a gravidez lhe faltava ${ }^{10}$.

As três irmãs não concluíram o ensino fundamental, moravam com os pais e mais quatro irmãos. Essa família vivia com muitas dificuldades financeiras em consequência de não ter produção agrícola em seu lote. Alimentava-se da coleta de alimentos disponíveis na mata nativa e, mensalmente, recebia os recursos dos Programas Sociais "Bolsa Família" do Governo Federal e "Mesa Brasil” do Sesc-Serviço Social do Comércio. Mas, comentava-se em Abacatal que parte desses recursos era gasta, diariamente, com o consumo de bebidas alcoólicas pelos pais.

8 A expressão "de fora", indica uma categoria nativa utilizada para identificar as pessoas e os lugares que não integram o território de Abacatal e a outra, "de dentro" é utilizada no sentido contrário.

9 Negar uma paternidade significa acusar a menina de ser periguete, como assim é identificada em Abacatal. Essa expressão é muito presente nos nossos dias, utilizada para depreciar uma mulher que se relaciona sexualmente com os parceiros que desejar, sendo vista, deste modo, como uma mulher vulgar (assanhada, foguenta, como se adjetiva em Abacatal), isto é, uma mulher que não serve para casar. É a "mulher errada", a "mulher da rua", uma oposição à "santamãezinha", como aparece nos estudos Mary Del Priore (1993). Ainda não é uma prática em Abacatal se recorrer juridicamente ao reconhecimento de paternidades no caso de meninas acusadas de periguetes, pois sabem que não terão apoio da própria família, nem da do rapaz e nem da comunidade. Preferem o silêncio porque não querem correr o risco de sofrer mais discriminação. Por isso, ainda, é preferível dizer ao filho que o pai dele é o "pai do céu". Assim como estudou Mead (2009), muito se assemelha o caso dessas meninas com as meninas Mundugumor não virgens que, do mesmo modo, têm seu "valor" prejudicado para o casamento. Situações parecidas também estudou Syane de Paula Lago em sua dissertação de mestrado Namoro pra casar? Namoro pra escolher (com quem casar): ideias e práticas de namoro entre jovens em Belém/PA. 2002.

10 Mulheres e homens mais velhos diziam que na época em que eram moças e rapazes as meninas engravidavam bem novas devido o acesso ao estudo ser difícil e a única perspectiva que tinham era a de constituir família, diferentemente, das condições de hoje. 
Ser um trabalhador/tornar-se um abacataense: criança, socialização e aprendizagem em uma comunidade quilombola da Amazônia-PA

Assim, como no caso das três meninas, acontece o nascimento de uma criança na vida da maioria das mocinhas e moças abacataenses. E, como dito por elas: fruto de uma "cabeçada", que significa contrariar uma orientação endereçada às meninas ${ }^{11} \operatorname{logo}$ que se tornam mocinhas ${ }^{12}$ : não ter filhos muito nova e/ou quando não se tem marido, ou quando o rapaz de quem se engravidou é um preguiçoso e "só quer saber das coisas lá de fora", quando é casado, ou "um malandro lá de fora" e, ainda, quando estão cursando a escola básica. Em Abacatal espera-se, no mínimo, que uma moça conclua o ensino médio para pensar em casar e ter filhos e que o rapaz escolhido seja trabalhador e, de preferência, esteja empregado de carteira assinada na cidade. São as condições que aquela mulher de olhar triste possuía. O menino, assim que vão ficando rapazinho, também é orientado a não abandonar os estudos e a não ter "relacionamento sério" com meninas periguetes, isto é, não pensar em casamento. ${ }^{13}$

11 Pensamos que seja parecido em tantos outros lugares, tão perto e tão longe das meninas abacataenses, no tempo e no espaço, onde, do mesmo modo, regras são contrariadas, como estudou Ana Lídia Pantoja (2007).

12 Em Abacatal a mocinha tem como marcador a primeira menstruação e o rapazinho o engrossar da voz e o aparecimento dos primeiros pelos da barba e do bigode.

13 Um projeto aliado ao que os abacataenses chamam de "bom partido" para a filha, que corresponde à perspectiva que se mantém entre eles que é a qualidade de um Keim bom, como analisa (Woortmann, 1994, p. 128): "As qualidades que expressam um Keim bom são, para o homem: diligência, capacidade de organização da unidade produtiva, força física, prudência e iniciativa, cumprimento da palavra empenhada, senso de justiça, ausência de vícios (bebida, jogo e mulheres), obediência às regras de reciprocidade, conformidade aos princípios de hierarquia (respeito e obediência ao pai e aos representantes da Igreja) e solidariedade para com os parentes e vizinhos. O Keim bom para a mulher inclui essas mesmas qualidades, além de outras que dizem respeito ao seu papel na reprodução social e biológica da família, pois ela deve ter virtudes morais". Não ter essas virtudes é possuir Keim ruim. Quando um dos cônjuges possui o keim ruim contamina os filhos. Assim como são vistos em Abacatal o casal que gasta os recursos dos Programas Sociais com bebidas alcóolicas, tem três filhas mocinhas que engravidaram novinhas e filhos rapazes acusados de envolvimento com atos ilícitos: drogas, brigas e furtos. 
O namoro e o casamento com rapazes e moças "de fora" são desejos da juventude abacataense. Esses rapazes e moças são percebidos como sendo mais interessantes, devido possuírem uma aparência que agrada essa juventude e aparentarem melhores condições financeiras: estão sempre vestidos, calçados e de cabelos cortados e pintados em conformidade com a moda e têm uma linguagem permeada pelas gírias do momento, por isso, para ambos, tornam-se mais desejáveis. Mas também, algo maior se impõe através dos tempos na vida da juventude abacataense e alhures, que é a ideia de que "ser da cidade", ou seja, ser de um lugar com mais prestígio e dominar códigos considerados dominantes, significa acompanhar o progresso, o avanço, enquanto que as áreas rurais são vistas como lugares do atraso, do ultrapassado (CARNEIRO, 2012). Imbuídos dessa representação, muitas moças e rapazes, no momento da "paquera", não se apresentam como moradores de Abacatal, e sim de Ananindeua ${ }^{14}$, mas, mesmo assim, o acesso a esses pretendentes, isto é, ao mercado de solteiras e solteiros, não é tão fácil, pois depende de uma série de investimentos, inclusive, financeiros.

A iniciação sexual das moças e rapazes abacataenses - que começa entre seus grupos de pares em uma idade muito tenra, dá-se por meio das brincadeiras e conversas que proporcionam prazer e satisfazem curiosidades no tocante ao aspecto e à função dos órgãos genitais ${ }^{15}$ - na maioria das vezes o ato sexual acontece com "os de dentro", sendo que, segundo os adultos, fazendo uma comparação com o tempo quando eram jovens, "está começando cada vez mais cedo". Contudo, nas longas conversas, principalmente, com as mulheres, foi observado que também se viam como uma daquelas moças que não seguiram as orientações, mas atribuíam às "cabeçadas" (a perda da virgindade com um "homem desqualificado" e a gravidez ainda mocinhas) a pouca informação que possuíam. Consideravam-se "bobas", enquanto que as "cabeçadas" das

$14 \quad$ Município onde Abacatal é jurisdicionado.

15 Com a liberdade mais cerceada, ou melhor dizendo, com limites mais direcionados por tabus, preconceitos e de perspectivas de futuros maridos e esposas para os filhos, é possível dizer que a "iniciação sexual" dos abacataenses aproxima-se dos estudos de Malinowski (1983) sobre a vida sexual das crianças nas ilhas Trobriand, de Margareth Mead (1928/1961) sobre a adolescência em Samoa e de Motta-Maués (1993) sobre o namoro e o casamento em Itapuá. 
Ser um trabalhador/tornar-se um abacataense: criança, socialização e aprendizagem em uma comunidade quilombola da Amazônia-PA

meninas de hoje em dia, para elas, ocorrem devido o "assanhamento". Isso sinaliza uma localização que fazem dos universos da sexualidade e da maternidade femininas, historicamente, fabricados entre nós nas bases do "Brasil Colônia", como discute Del Priore (1993).

Mas, eram as crianças que instigavam e forçavam a conversa sobre o tema da sexualidade e escandalizavam as avós. Elas não gostavam de ouvir as crianças comentando certos assuntos que diziam aprender na escola ou pela televisão, principalmente os relacionados à relação sexual, órgãos sexuais, doenças sexualmente transmissíveis, homossexualidade, preservativos e contraceptivos. No entanto, as mães gostavam, porque dividiam com a escola a responsabilidade de falar desses assuntos e, assim, aliviavam as cobranças de serem vistas como as únicas responsáveis pela gravidez da filha mocinha.

O casamento na vida de uma menina que já têm filhos ocorre, na maioria das vezes, quando ela encontra um homem para se "juntar", que também já tem filhos. O esperado é que esse homem a leve da casa dos pais junto com os filhos e passe a sustentá-los, assumindo o seu papel de provedor. A condição de provedor do homem não exime a mulher dos seus compromissos com o trabalho; por isso mulheres e homens se consideram pessoas trabalhadoras, sendo uma ofensa sem tamanho ser chamado de preguiçosa e de preguiçoso. A "pessoa preguiçosa" é vista como frouxa, fraca, indisposta que, com certeza, vai se tornar uma "pessoa doente" e terá sua honra abalada. Por isso, trabalhadeiras é como ambos esperam que suas crianças se tornem, pois ninguém quer uma filha, um filho, ou neta e neto, adjetivados nesses termos.

Para os abacataenses, o feto de uma "menina fêmea" custa mais a se gerar, por isso até os três primeiros meses tem o formato de uma "bola". Se a mulher abortar uma menina durante esses três primeiros meses vai expelir uma "bola". O "menino macho" com três meses tem a forma de um "lagarto". O feto da menina é comparado a uma "bola" porque só começa a "mexer" entre cinco e seis meses de gestação, dizem que é mais preguiçosa, por isso demora a tomar forma, enquanto o do menino "mexe" a partir de um mês, porque é mais "estrapoloso", "danado", "esperto". E mais preguiçosa a menina vai ser se nascer na lua minguante, pois já começa a demonstrar lentidão ao atrasar o trabalho de parto. Algumas mulheres, as mais atuantes na vida política de Abacatal, consideravam que a desvalorização do trabalho delas e o fato de serem chamadas de 
preguiçosas pelos homens, também têm origem nessa explicação do formato e da destreza dos fetos.

O processo de desenvolvimento infantil é marcado pela diferenciação entre "meninos fortes" e "meninas fracas". Às meninas, cabem determinadas tarefas, as consideradas mais leves e menos perigosas; aos meninos, as mais pesadas e que envolvem certos perigos como expressou Herb em uma conversa com Glicínia em meio a outras cinco meninas: Eu pego no terçado e tu só na faquinha [risos]. Mas porque é perigoso, respondeu a menina. Não é não, porque eu sou mais forte que tu [risos]. As meninas entenderam o tom depreciativo do menino e avançaram para bater nele. Ante as observações sobre (cuidar d') as coisas de meninas e meninos abacataenses e sobre este diálogo, compreendemos que essa diferenciação permeia o modo como meninas e meninos são socializadas no e para o trabalho. Este ponto será retomado adiante.

Os meninos, entretanto, quando se tornam adultos, são vistos pelas mulheres adultas como pouco dispostos para o trabalho e para o estudo. Essas percepções de "mulheres trabalhadeiras" e de "homens preguiçosos" são inversas ao modo como interpretam a forma e a destreza de um feto do sexo feminino e do sexo masculino. Por isso mesmo, ser trabalhador não é algo dado naturalmente, pois nem o homem e nem a mulher nascem trabalhador ou trabalhadora em Abacatal, mas torna-se. Sob essas percepções, muitos rapazes abacataenses, segundo a apreciação das mães, não servem para casar com suas filhas e gerar um filho.

Diferentemente da percepção de moças e rapazes sobre os pretendentes "de fora", Dona Violeta muito se orgulha do fato de três entre suas seis filhas terem casado com homens "de fora", porque, para ela, os homens daqui não gostam do trabalho, por isso são tudo frouxo, parado, por isso que a gente vive sendo ameaçado de perder nosso terreno. Tá certo que os 'de fora' não se envolve com isso, mas dão o sustento. Por esse motivo, Dona Violeta também não deseja que suas netas tenham filhos com os homens "de dentro". Valeriana, 11 anos, disse que sua mãe a colocou para estudar "prá fora" porque não quer que se envolva com os meninos abacataenses. Eles são malandros, não querem nada, observou a menina.

Nesse sentido, esperam que as filhas procurem homens trabalhadores para casar e ter filhos: esses homens são vistos como vigorosos. As mulheres, particularmente, as envolvidas com o trabalho da roça, assim como Dona Violeta, sempre comentavam que quando não 
Ser um trabalhador/tornar-se um abacataense: criança, socialização e aprendizagem em uma comunidade quilombola da Amazônia-PA

trabalhavam se sentiam doentes e, se adoecer, não se pode deixar o corpo "esmurecer"; deve-se continuar trabalhando, senão, como proferiu a mulher: a doença toma conta. Quero morrer quando o meu corpo não puder mais trabalhar. Assim foi com a minha mãe, morreu trabalhando. Margarida, sua filha, entende que seu pai vive doente porque nunca gostou de trabalhar. Como discute Sarti (2010, p. 91): “O corpo é o instrumento do trabalho, não apenas para sobreviver, mas para mostrar-se forte. Também a saúde tem um valor moral". Assim, a disposição para trabalhar, vista como qualidade positiva, como honra, compensa as desigualdades sociais e étnicas (CARDOSO DE OLIVEIRA, 2004), como comentou Dona Gezânia com forte influência política dentro da comunidade: somos pobres e pretos, mas somos trabalhadores.

Para os homens abacataenses, o trabalho das mulheres é leve, são ajudas, tal como também percebem, nessa consideração, o trabalho das crianças; por isso dizem que não se compara ao deles, como estudou Garcia Jr. (1983). Elas são é umas faladeiras, nós pegamo é no pesado, quero vê elas fazerem o que a gente faz, tô dizendo isso porque também não gosto de cabra preguiçoso, porque não quero que a minha filha se case com um desses, comentou o marido de Margarida. Essa diferença entre percepções de homens e mulheres, acerca de suas relações com o trabalho, é motivo de muitas desavenças entre casais e entre filhas e pais quando, novas demais, engravidam de "rapazes preguiçosos", ou quando casam com homens sem iniciativa para o "trabalho de verdade" e que ficam sob o sustento da mulher e da sua família.

A orientação, como mencionado, é contrariada, porque os namoros e relações mais íntimas são inevitáveis entre moças e rapazes "de dentro", e, tradicionalmente, ainda, vigora o habitus que orienta a escolha de parceiros que sabem viver no e daquele lugar, mesmo sob o desejo de um parceiro "de fora" e as constantes desavenças provocadas pelas rivalidades e conflitos entre consanguíneos e afins. Os três troncos de famílias que deram origem a Abacatal (Seabra, Costa e Barbosa) se mantém, pois antigas formas de constituição do parentesco se fazem presentes na organização da vida social (FIRTH, 1974) abacataense, como o casamento de primos cruzados bilaterais que se realiza comumente dentro de uma moldura endogâmica local (VIVEIROS DE CASTRO, 1995), mas que se atualiza em conformidade com as suas percepções sobre a luta pelo território. 
Maria Amoras

Maria Angelica Motta-Maués

\section{A vida no lote familiar e a infância}

Os matrimônios são estratégias familiares eficazes na condução das decisões dentro da comunidade e do estabelecimento de laços de solidariedade, sendo facilitados pela distribuição da terra em lotes familiares que, por sua vez, implica um sentido singular das crianças viverem a infância em meio aos adultos. Esse modelo possibilita aos grupos familiares, estabelecidos em um determinado lote, compartilhar o cuidado com as crianças, repartir alimentos e fazerem refeições juntos (às vezes no mesmo prato), prestar assistência aos doentes, criar momentos de lazer, participar do trabalho de modo coletivo, dividir despesas, criar animais e plantar juntos.

Nos terreiros, ao redor das casas, é comum os pais e avós plantarem árvores frutíferas para as crianças, como também, lhes darem pintos para criar, atividade que dizem fazer por gosto. Dentro da mata, na extensão de seus lotes, onde "botam" suas roças, é comum ser doado a elas um "pedacinho de roça". E, cada uma cuida diariamente daquilo que é seu. As crianças também têm o costume de trocar, emprestar, vender e presentear suas criações e os frutos das plantações. Aqui e ali, uma criança faz um canteirinho, misturando verduras, plantas medicinais e ornamentais.

Nesses terreiros, dispostos em lotes familiares, crianças e adultos, pelo trabalho, exploram a mata nativa e circulam de uma casa para outra, transacionando as trocas, as obrigações de dar, receber e retribuir e as solidariedades (MAUSS, 2003). Esse conjunto de coisas e de momentos compartilhados faz com que as crianças se percebam como fazendo parte de uma única família, como comentou Iris, nove anos, referindo-se ao lote da casa da avó materna, onde mora com a sua mãe, o padrasto, dois irmãos menores e um primo, e as casas das famílias de mais duas tias maternas: olha, aqui nessa terra toda mora nossa família. ${ }^{16}$

16 Esses tempos e espaços territorais possibilitados na infância das crianças são fundamentais para o tornar-se abacataense. A socialização e a aprendizagem mobilizam um conjunto de "técnicas de corpo" enquanto atos tradicionais, tal como demostradas por Mauss (2003, p. 407): “Chamo de técnica um ato tradicional e eficaz (e vejam que nisso não difere do ato mágico, religioso, simbólico). Ele precisa ser tradicional e eficaz. Não há técnica nem transmissão se não houver tradição. Eis em que o homem se distingue antes de tudo dos animais: pela transmissão de suas técnicas e muito provavelmente por sua transmissão oral. [...] ". 
Ser um trabalhador/tornar-se um abacataense: criança, socialização e aprendizagem em uma comunidade quilombola da Amazônia-PA

Oleandro, nove anos, dizia com muito orgulho que ele é Costa e Barbosa, isso significa fazer parte de uma família bem maior que as demais. Herdar dois sobrenomes do tronco é ter mais força na descendência, que possibilita mobilizar prestígio e negociar. Nesse sentido, a família em Abacatal "é um conceito também genealógico, isto é, que tem a ver com as relações estruturais dadas pelas regras de descendência”" (PANTOJA, 2004, p. 225). Quando um abacataense evoca seu sobrenome está se reportando à sua raiz. Assim, como estudou Woortmann (1994, p. 08): “A 'árvore' é uma forma de pensar o tempo - um tempo genealógico, poder-se-ia dizer. Os membros mais antigos, localizados num tempo histórico-mítico, constituem a 'raiz' da 'árvore'". Observei do mesmo modo que em Abacatal "a relação simbólica entre raiz e árvore 'natural' e 'social' é evidente. Tais árvores, na medida em que ainda existam, constituem um marco histórico da família, isto é, da memória de parentesco"; são como a autora define: "lugares da memória", sinalizando um "tempo estrutural", com também especifica Evans-Pritchard (2011). ${ }^{17}$

Como o casamento entre primos cruzados e bilaterais é o que mais se efetiva, as crianças são socializadas e educadas para tornarem-se trabalhadoras/abacataenses, como justificou Dona Violeta, no momento em que estava junto com o seu neto rachando ${ }^{18}$ lenha: veja, não exploro o meu neto, não vejo o que ele faz como trabalho infantil, que eu tô explorando ele, como o conselho tutelar vem aqui dizer pra nós... que a criança não pode trabalhar. Eu ensino ele, porque ele vai crescer e vai casar com uma mulher daqui e tem que saber fazer as coisas daqui, não é mesmo? Ou vai viver como um homem preguiçoso, sem disposição pra nada, aí, os filhos vão ser tudo igual.

Dona Dália, mãe de dois filhos rapazes e uma filha de oito anos. Com ela morava a filha e uma sobrinha que tinha uma filha mocinha de 14 anos e duas meninas gêmeas de sete anos. Mantinha-se com a venda dos produtos da roça, do benefício do Programa "Bolsa Família" e das diárias

17 "O parentesco, portanto, se relaciona à memória de diversas maneiras, mas poder-se-ia dizer que, na medida da ênfase posta na descendência - e a aliança se destina a assegurar a descendência, a 'casa' e a 'árvore' - o parentesco é memória" (WOORTMANN, 1994).

18 "Rachar lenha" é uma atividade de cortar a madeira em pedaços com machado. As lascas da madeira são usadas para ascender o fogo dos fogões de cozinha e os fornos de carvão. 
que a sobrinha recebia trabalhando na fábrica de reciclagem de lixo na cidade. Para as meninas, que ainda eram crianças, faziam uma roça especialmente para a compra dos presentes de aniversários e de natal e de algumas poucas peças de roupas para cada uma vestir nessas datas. As meninas participavam do trabalho, como comentou Magnólia, de sete anos: a gente capina mato fino e sameia, agora, derrubar, capinar mato grosso, queimar, coivarar e arrancar... é tudo a mamãe e a titia que faz. Nós capina sentada, porque quando a criança senta, encosta a bunda na terra, o mato demora a crescer [risos]. Dona Dália, assim como Dona Violeta e várias mães e pais abacataenses, também observavam: não exploro elas, apenas ensino a vida do mato. Quem vévi no mato deve saber lidar com ele. E, se elas casarem com um homem do mato e morarem aqui, não vão se aperrear com os filhos.

Por isso, todo menino abacataense deve saber apanhar açaí, e quem não sabe serve de "chacota" para os demais. A menina aprende essa prática muito mais pela brincadeira, ou na falta de um menino, porque não é um trabalho próprio delas. O menino tem a obrigação de saber, devido o açaí ser um alimento básico em Abacatal e, quando casar, deverá garanti-lo à sua família. Nesse caso, para os meninos, saber apanhar açaí é uma questão de honra (BOURDIEU, 2002), pois deverá tornar-se, como estudaram Woortmann \& Woortmann (2004): um "pai-de-família", ou como está pensado em Abacatal: um trabalhador/abacataense.

Antúrio, nove anos, foi "chacoteado" por um grupo de meninos quando disse que não sabia subir no açaizeiro. Um deles o desafiou de modo ríspido: quero ver tua mulher pedir açaí e tu não saber pegar. Como vai ser? Antúrio respondeu com um sorriso tímido expressando vergonha. O grande receio dos adultos é que as crianças cresçam e casem com um "homem ou uma mulher daqui sem saber fazer as coisas daqui", pois entendem que a continuidade do grupo e a dignidade da pessoa, isto é não ser acusada de preguiçosa (que significa ser "fraca", "parada", "frouxa", "doente") - dependem da continuidade do saber (cuidar d') as minhas coisas, isto é, tornar-se um abacataense.

\section{O trabalho das crianças e seus significados}

A perspectiva do tornar-se, construída por Toren, permitiu considerar que as crianças abacataenses, nas suas relações cotidianas, junto aos adultos e a outras crianças, em um processo de constituição de si e de 
Ser um trabalhador/tornar-se um abacataense: criança, socialização e aprendizagem em uma comunidade quilombola da Amazônia-PA

seu grupo, produzem significados sobre o trabalho. Significados que revelam a maneira como participam da organização social do seu grupo. Para isso, foi primordial considerar a intersubjetividade ${ }^{19}$ proposta por Toren (1999) - lembrando também Gilberto Velho (1987), e sua referencial análise sobre construção da subjetividade e família -, como instrumento analítico para a compreensão do modo como as crianças vivenciam as condições de trabalho e a infância, e também o que as crianças fazem especificamente dessas condições, isto é, os significados que as crianças produzem e compreendem.

O modo, portanto, como essas condições são vividas pelas crianças, e aquilo que fazem delas, as tornam quem elas são. Isto significa dizer que "em qualquer ponto específico na linha do tempo, nossas descrições do mundo e de nós mesmos são artefatos da micro-história incorporada que torna a cada um de nós quem somos" (TOREN, 2010, p. 40), sustentáculos da imaginação. Entendimento que, leva-nos a sustentar a tese de que uma criança de Abacatal vai crescer para ser um adulto que mantém por princípio e prática "o modo de vida abacataense". Então, essa pessoa precisa tornar-se alguém - "self futuro específico" (TOREN, 2011) -, aquela que toma o trabalho materializado nas suas obrigações com ela mesma e com a família em geral, e/ou a sucessão de gerações trabalhadoras e se torne compreensão pressuposta do sentido da vida abacataense.

É pertinente esclarecer que na recolha dos dados não foram direcionados instrumentos às personalidades futuras das crianças, para evitar que respostas fossem produzidas conforme aquilo que achavam que era esperado, pois, como sabemos, acontece (ou pode ocorrer) de as crianças, assim como a maioria das pessoas, quererem atender às expectativas de quem os aborda numa pesquisa. Na organização dos dados, essa questão apareceu nas referências das observações, na leitura de diários e das redações escritas pelas crianças, nas interpretações que fizeram de seus desenhos, nas fotografias e vídeos gravados por elas mesmas, nas conversas informais e brincadeiras ao longo do trabalho de

\footnotetext{
19 "A intersubjetividade inevitavelmente informa todo aspecto - inconsciente e consciente - daquilo que conhecemos e daquilo que experienciamos [...] a ideia que fazemos de nós mesmos enquanto sujeitos vai se constituindo como função da intersubjetividade - um processo de contínua diferenciação, em que estamos sempre nos tornando nós mesmos" (TOREN, 2006, p. 466).
} 
campo. A intenção aqui é mostrar, de modo ampliado, as crianças e suas vivências cotidianas com atividades que identificamos como trabalho, ou na versão êmica, inclusive das crianças, o (cuidar $\left.d^{\prime}\right)$ as minhas coisas.

\subsection{O que as crianças pensam sobre o futuro}

Meninos e meninas, entre oito e dez anos de idade, escreveram em suas redações o que queriam "Ser" e "Ter" quando tornarem-se adultas. As meninas mostravam interesse em ser professora, diretora da escola, médica, dentista, enfermeira, cantora, atriz, modelo e bailarina; enquanto os meninos queriam ser advogado, empresário, cantor, jogador de futebol, médico, veterinário, bombeiro, promotor, policial, motorista, vereador, prefeito, presidente e Manoel ${ }^{20}$. Quanto aos papéis dentro da família, as meninas se imaginavam sendo mãe de bebezinho fofinho e que cuidará da mãe que vai estar bem velhinha; enquanto os meninos se imaginavam sendo pai trabalhador e austero, aquele que castiga o filho, trabalha "pra fora" e que cuidará da avó. No quesito "Ter", as meninas desejavam possuir uma casa com televisão, som, aparelho de DVD, geladeira, fogão, mesa com cadeiras, sofá, cama, computador, almejam também uma motocicleta e um carro, muitas roupas e maquiagens; enquanto os meninos, desejavam possuir carro, caminhão, motocicleta, videogame, computador, motosserra, camisas e sandálias de marcas, celular com internet. Nem precisamos ressaltar as injunções tradicionais de gênero na diferença das respostas de meninas e meninos abacataenses.

As preferências das crianças confirmaram que a imaginação sobre o futuro é mediada por suas relações com os outros. E como lembra-nos Toren (2010, p, 39): “assim também é tudo o que dizemos e fazemos, até nossos sonhos mais íntimos. Subjetividade só pode ser uma função de intersubjetividade". Constatação que leva a compreender porque as crianças não se veem no futuro fora de Abacatal, embora mantendo as suas relações de interação com "os de fora", exercendo profissões identificadas como sendo próprias de mulheres e de homens, como as de professora, médica e médico, enfermeira, advogado e outras não citadas pelas crianças, como as de assistente social e de engenheiro ambiental, que têm sido

20 Manoel é o nome de um mototaxista que faz frete para os moradores de Abacatal. As crianças pequenas indicam esta profissão pelo nome do profissional devido não saberem pronunciá-la. 
Ser um trabalhador/tornar-se um abacataense: criança, socialização e aprendizagem em uma comunidade quilombola da Amazônia-PA

pleiteadas por alguns jovens abacataenses na universidade pública, pela "política de cotas para quilombolas". Quanto aos desejos pelos objetos, são alimentados não somente porque ouviram falar dessas coisas, ou viram na televisão e nas lojas da cidade, mas porque percebem que algumas pessoas dentro de Abacatal possuíam alguns deles.

As crianças também se imaginavam assumindo os papéis definidos (e assumidos) pelas mulheres e pelos homens adultos e casados, correspondendo, deste modo, às expectativas alimentadas com o seu nascimento, para que se tornem "pessoas de bem" e "alguém" - o que implica um "eu moral" e uma posição social. A obrigação de ser solidário é um dos pontos que as crianças vislumbram para o futuro, porque a solidariedade evidencia uma das particularidades da vida abacataense, como a obrigação de cuidar daqueles que um dia cuidaram delas: mães e avós. Quando as crianças estiverem adultas, o cuidado com essas pessoas integrará o conjunto de atividades do (cuidar d') as minhas coisas. Elas têm clareza de que, no futuro, essas pessoas estarão mais velhas, e caberá a elas esse cuidado. Como presenciavam acontecer com as gerações ao seu redor. Evidentemente que não sem seus percalços e conflitos.

A presença do cuidado com esses parentes parece dizer que formas de relacionamento tradicional, pautadas em uma ética ${ }^{21}$, precisam continuar "e com elas a ideia do self como um locus de relacionamento" (TOREN, 2010, p. 39). Como a autora discute: "a probabilidade de que isso venha a se repetir tem tudo a ver com o modo como construímos significados a partir de significados que outros construíram e estão construindo", considerando que se trata de um "processo no qual os significados são mantidos até

21 Uma ética que se eleva como senso de justiça, ou seja, de retribuir uma dádiva; contudo, o "cuidado" que as crianças dizem que terão com suas mães e avós, inspira-nos a pensar não como uma "reciprocidade" que compromete sua gratuidade, mas como reflete Lévinas (2010, p.262): uma ordem da justiça dos indivíduos responsáveis uns pelos outros que "surge não para estabelecer esta reciprocidade entre o eu e seu outro, mas por causa do terceiro que, ao lado deste que me é um outro, me é 'também um outro'". Neste sentido, também cabem as reflexões de Kátia Mendonça (2013, p. 63) para pensar esta ética, referida, enfaticamente, pelas crianças abacataenses, que, nesta leitura, "pode ser entendida como uma visão espiritual do Outro, em sua diferença e ao mesmo tempo em sua ligação conosco, como parte da criação que somos". 
mesmo enquanto são inevitavelmente transformados". Dessas "obrigações do parentesco" trata Motta-Maués (2008;2009), quando discute o "costume" (e suas transformações, diante da mobilidade social ascendente das famílias estudadas) de receber e criar, como "filhos de criação", filhos de parentes, o qual é uma das modalidades da prática da "circulação de crianças", na Amazônia.

Partilhando da ideia do indivíduo como sujeito de suas próprias escolhas, é possível afirmar que tornar-se trabalhador/abacataense não significa, consequentemente, tornar-se uma trabalhadora/um trabalhador rural, uma camponesa/um camponês dependente da renda do empreendimento com a terra para o sustento do seu grupo, visando sua reprodução enquanto tal, mas uma trabalhadora/um trabalhador que carrega na base de sua formação o conhecimento da lida com a terra, da reprodução de seus recursos e do trabalho doméstico e coletivo (solidário), como mostraremos adiante. No entanto, como também compreende Toren (2010), não se pense tampouco que a defesa da ideia de ser "agente de suas próprias escolhas" significa que este estudo esteja sugerindo que as ideias abacataenses, assim vividas, escapam das "misérias humanas" que a vida costuma encontrar em qualquer tempo e em qualquer lugar.

\subsection{A criança trabalha ajudando}

A ajuda das crianças é presente no cotidiano dos abacataenses, seja na rede de parentesco ou de vizinhança. É comum as mães mandarem seus filhos ajudar os avós, tios e tias, padrinhos e madrinhas quando estão doentes, ou quando estão sobrecarregados de trabalho e, ainda, quando o tempo é curto para o preparo de uma festa. As crianças nem sempre esperam ser mandadas pelos adultos, é comum vê-las se oferecendo para ajudar. Elas sabem que o ato de ajudar é aprendido, como declarou Iris, na cerimônia de sua "primeira eucaristia": aprendi a amar, respeitar e ajudar os outros que precisam de ajuda, certamente referindo mais um reforço àquela ética na preparação para o ritual.

Criar as crianças nessa perspectiva também é reveladora de uma moral e uma ética que permeiam o modo como suprem parte de suas necessidades cotidianas. Contudo, os adultos não entendem a ajuda dos 
Ser um trabalhador/tornar-se um abacataense: criança, socialização e aprendizagem em uma comunidade quilombola da Amazônia-PA

pequenos $^{22}$ nas relações de trabalho como sendo trabalho, pois insere-se como elemento simbólico no processo de uma dádiva - embora elas executem atividades concretamente, ainda que, ao mesmo tempo, brinquem de executá-las. Por sua vez, as crianças abacataenses reformulam essa ideia, para elas: a criança trabalha ajudando. Gardênia, 13 anos, comentou: eu trabalho para ajudar os meus pais trabalharem 'pra fora' e também porque devo aprender a fazer as coisas; não sabemos o dia de amanhã.

A ajuda, no contexto deste estudo, analisada a partir de como os adultos e as crianças a expressam nas relações de trabalho, é uma categoria que impõe elementos simbólicos significativos. Os adultos não veem a ajuda das crianças nas relações de trabalho como sendo trabalho, por isso pauta-se em uma relação de dependência das crianças com os adultos, mediada pela hierarquia geracional e por um entendimento da criança como pessoa imatura, com limitações físicas e intelectuais. As crianças veem a ajuda que prestam nessas relações como trabalho e sentem-se partícipes importantes dele, razão pela qual esperam, por vezes, recompensas dos adultos. De caráter político, econômico, religioso e doméstico, a ajuda das crianças marca os momentos em que o capital simbólico do grupo circula entre seus membros, fortalecendo aquilo que os une e estruturando o modo como veem o mundo e como concebem as crianças e a educação a elas destinadas.

As crianças, assim como Gardênia, assistem às investidas e buscas fracassadas dos jovens nas suas saídas "pra fora". Também pensam que a qualquer tempo o responsável pela sua criação pode faltar, e o pequeno terá que enfrentar as intempéries da vida. Para os adultos, como corre-se o risco da escola não cumprir o seu papel, o mais previsível é que a criança sobreviva por meio dos conhecimentos adquiridos junto à família. Esse é mais um dos motivos para que tenham a ajuda requisitada, evitando que cresçam sem nada saber fazer. Porém, o trabalho doméstico, que são as obrigações, não é visto com entusiasmo pelas crianças, assim como também não agrada os adultos, mas as crianças compreendem sua importância e seu dever de participação nele: Se não fizer, não come, se fizer só um não dá prá assustentar todos, não pode só um fazer, então, todos tem que fazer, comentou

22 Para os adultos os pequenos que "já ajudam" estão classificadas entre sete e quinze anos de idade, enquanto, para as crianças, começa mais cedo, aos quatro anos. 
Yuca, de nove anos; e Jasmim, também de nove anos, acrescentou: já pensou, só o pai e a mãe fazendo e o resto só olhando? Não tem condição, né?

Ir ao "socorro" e "colaborar" com alguém consistem em "bondades", como comentou Verônica:

pode ficar chateado porque se vai fazer um trabalho que não vai receber nada, mas compensa porque estamos ajudando alguém, fazendo o bem. Também, por exemplo, varrer o terreiro pra vovó, ninguém recebe dinheiro, mas vamos ganhar dela o terreiro limpo pra brincar.

As crianças também demonstram entusiasmo pelo trabalho realizado no preparo e durante a realização das festas: nós trabalhamos, comemos, rezamos, brincamos, dançamos. Tudo ao mesmo tempo ${ }^{23}$.

Entre as crianças, são as ajudas que lhes possibilitam passar tempos na casa de um parente, isto é, como já mostraram Fonseca (1995), MottaMaués (2004), Gregori (2000), a "circular": fui ajudar minha irmã a carregar umas tábuas na casa dela e, como tava bom pra mim, ainda estou por lá, comentou Ypê, de 10 anos. Assim, a assertiva das crianças "A criança trabalha ajudando", levou a compreensão de que os abacataenses vivem suas vidas em torno da ideia de uma socialidade humana manifestada na obrigação mútua, na reciprocidade, nos cuidados, nos contratos, nas trocas e nas solidariedades.

\subsection{Quanto tu vai me dá?}

Para as crianças certas ajudas obrigatórias, quando motivadas por uma pequena retribuição financeira, são boas de serem realizadas e deixam

23 Brandão (2009, p. 39-53) apresenta uma interessante discussão quanto à organização desse tipo de trabalho. Com base nos estudos de Marcel Mauss (2003, p. 212) é possível compreender o significado de trabalho atribuído à realização das festas pelas crianças, como envolvendo situações em que o trabalho produtivo e o trabalho simbólico fundem tempos e lógicas de suas relações sociais. "No fundo são misturas. Misturam-se as almas nas coisas, misturam-se as coisas nas almas. Misturam-se as vidas, e é assim que as pessoas e as coisas, misturadas, saem cada qual de sua esfera e se misturam: o qual é precisamente o contrato e a troca". 
Ser um trabalhador/tornar-se um abacataense: criança, socialização e aprendizagem em uma comunidade quilombola da Amazônia-PA

transparecer que serão feitas com mais eficiência, como as ligadas ao trabalho dos pais. Sempre ficam por ali a esperar um "trocadinho". Um pai, ao perceber que o filho realizava com mais dedicação a lavagem das garrafas em que armazenam tucupi, passou a remunerar essa ajuda com uma pequena quantia em dinheiro. Passei a dar um dinheirinho pra ele porque não pode crescer achando que o que ele faz não tem valor nenhum. Assim, a possibilidade de ganhar um dinheirinho também se soma àquelas que as crianças dizem fazer por gosto, como a que fez um menino, de 11 anos, montar a sua própria criação de galinhas.

Com o dinheiro da venda das galinhas, dos ovos, dos cestos de açaí, e também da bacaba e da pupunha, que o menino apanha, somado ao recurso que sua mãe transfere para ele do "Programa Bolsa Família", tem a possibilidade de comprar roupas, sapatos, sandálias e perfumes de marca. Certo dia, o próprio pai do menino ficou com uma dívida imensa com ele, porque pegava as galinhas e não pagava. O menino, dia e noite, ficava na cobrança e a dívida só aumentava. O "cobra, cobra", a "aperreação" do menino, como o pai se referia, o aborrecia: vê só em que tempos estamos... pai dever pra filho; pode isso? Onde já se viu pai negociar com filho?

O menino, no entendimento do pai, parece ferir a ética e a moral de um lugar que ainda conserva princípios de uma lógica camponesa, onde, tomando as reflexões e o título do estudo de Woortmann (1990), "com parente não se neguceia": "negociar" com um filho, uma criança, fere a moral da hierarquia e da reciprocidade entre pai e filho. Neste sentido, isso confirma o que Woortmann (1990, p. 16) sinaliza: “A trajetória camponesa não é, contudo, linear. Um movimento que se dirige a uma dimensão da modernidade pode ser, ele mesmo, necessário para que haja um outro movimento, o de reconstituir a tradição".

Noutra situação observada, uma menina de dois anos de idade e um menino de três, raspavam mandioca com uma colherzinha, pois ainda não tinham idade suficiente para pegar em uma faca. Quando a menina já estava com quatro e o menino completara cinco, puderam manusear a faca. Assim foram vistos ao longo da pesquisa, crescendo e participando da raspagem da mandioca junto aos familiares. As crianças também se sentiam motivadas pelos presentes das avós por estarem ali fazendo aquele trabalho, como os sorvetes. As avós diziam que é por meio dos "agrados" que elas conseguem a ajuda das crianças, mas também, porque não achavam justo as crianças não ganharem nada. É como se ficassem com 
pena delas. Brincando, aprendendo, ajudando nas tarefas de adultos (e nas delas e entre elas mesmas ao irem crescendo), assim vivem as crianças de Abacatal, assim participam ativamente da luta pelo território quilombola, igual a tantas outras de sociedades indígenas, cuja vida os relatos etnográficos nos mostram (cf. NUNES, 2003; COHN, 2002; SILVA \& NUNES, 2002).

As crianças sabem que os adultos gostam de trabalhar junto delas, por isso, impõem a negociação. A vovó diz que gosta de trabalhar com as crianças, porque quando a gente quer fazer, a gente faz direito, comentou Orquídea, de nove anos. As crianças se sentem orgulhosas desse reconhecimento. Os adultos sempre repetem isso quando estão nas "rodas de trabalho", como uma mãe disse às suas filhas e sobrinhos:

Olha, a minha avó dizia assim: 'é melhor trabalhar com dez crianças do que com um adulto'. O adulto a gente fica chamando e quando vem, vem sem gosto. A criança não, ela tá por ali, se aproxima, larga a brincadeira e faz com gosto, faz bem feito. Depois ela volta pra brincadeira e quando se lembra, volta de novo. Agora, adular um adulto, não tem condição!

Quando as crianças têm suas ajudas solicitadas é comum dizerem em tom de brincadeira, mas com a intenção: quanto vai me dá? [risos]. E, na brincadeira, terminam por ganhar uns trocadinhos. Contudo, algumas mães e pais remuneram as crianças pelo trabalho devido acharem que assim a ajuda não caracteriza trabalho infantil. Algumas crianças acham que o trabalho que fazem deve ser remunerado e têm clareza de que não podem ser exploradas, como foi o caso de uma mãe que pedia ao filho de oito anos que a ajudasse a carregar um saco de urucum, e ele retrucou: não posso trabalhar, a lei diz que criança não pode trabalhar. Sua mãe o repreendeu dizendo que ele não entendia de lei.

A resposta do menino mostra que ele se apropriou de um entendimento de que uma criança não pode ser explorada pelo trabalho, ou quem sabe, o trabalho não é para explorar as pessoas. Dona Afelandra, comentou: a gente tá vendo aqui que as crianças só querem ajudar se a gente tiver um trocado prá dar, é feio isso, ajudamos porque a retribuição são outras. Ambos 
Ser um trabalhador/tornar-se um abacataense: criança, socialização e aprendizagem em uma comunidade quilombola da Amazônia-PA

os posicionamentos convidam à reflexão de Brandão (2009, p. 51): “O que eles, os homens da terra, lamentam, o que lamentamos e não podemos aceitar é a perda do princípio de solidariedade, de gratuidade e de generosidade nas relações entre pessoas, entre grupos humanos e mesmo entre povos e nações". A socialidade e a pessoalidade, portanto, pensamos que são reivindicadas pelos abacataenses nesta perspectiva.

\subsection{Quando faz trabalho de adulto não é mais criança}

Em Abacatal "criança e trabalho" - a rigor, pessoa e trabalho - não se desvinculam, estão intimamente ligados e relacionados. Mas, ser criança é não fazer trabalho de adulto, observou e explicou Bromélia, 14 anos:

por exemplo, tinha uma menina, desde muito pequena, que a mãe colocava ela para fazer trabalho pesado: carregar e rachar lenha para encher o forno de carvão. Isso é trabalho de adulto e de homem, viu? E é muito difícil ver uma mulher fazer isso. Mas, isso aconteceu porque a mãe da menina só queria ter filho homem e tratava ela como um menino, aliás, como um homem. Sabe o que aconteceu? Ela engravidou com 13 anos. Pra mim, toda a culpa foi dos pais, porque, pelo fato da menina ser uma mulher, não podia trabalhar assim.

A criança trabalha em Abacatal no âmbito da vida doméstica, mas deve ser (ou pensam que está sendo?) na medida de seu desenvolvimento, caso contrário, como observou a menina, não é mais uma criança. $\mathrm{O}$ significado que a criança atribui ao seu trabalho/ajuda, o qual não se desvincula do modo como é solicitada a fazê-lo, evidencia também o modo como observa o adulto considerá-la. Uma ação que mobiliza os seguintes marcadores: sentidos (rejeição, obrigação, exploração, cooperação, diversão, gosto); relacional entre adultos e crianças (autoridade); temporal (ser criança), que diz respeito ao modo como querem ser percebidas, pois, assim como os adultos, querem se afirmar nesse lugar: eu brinco muito, mas vou trabalhando também. Levo horas capinando o terreiro, porque também tô brincando, sou criança, né?! Observou Lesser, oito anos. A percepção desses 
marcadores também é mobilizada pelas crianças para identificar, assim como Bromélia, o trabalho delas e dos adultos na medida das possibilidades e da condição de cada um: de gênero, física e geracional.

O trabalho pesado e forçado da criança também é percebido e contestado pela maioria dos adultos. Na conversa com as crianças e com os adultos sobre o tema do "trabalho infantil", ou seja, sobre a sua lógica da exploração, reportam-se ao caso de uma família onde as crianças, meninos e meninas, trabalhavam incansavelmente na feitura do carvão, a ponto de prejudicar a frequência e o desempenho escolar. Observaram que essa condição de trabalho das crianças foi uma imposição do pai, tanto que, logo após a sua morte, a mãe não permitiu mais que trabalhassem no forno. $\mathrm{O}$ entendimento de alguns pais sobre este caso foi de que o pai dessas crianças, desde muito pequeno, só conheceu a lógica do trabalho pesado e enfadonho.

Com base em Sarti (1996), compreendemos que o trabalho das crianças abacataenses, concebido a partir dessa lógica familiar, constitui-se em instrumento que viabiliza o projeto familiar e não individual, embora esta atividade seja realizada individualmente ${ }^{24}$. Um trabalho que faz parte do "ser criança" em Abacatal e em outros contextos desta parte da região amazônica, como encontrado nos estudos de Motta-Maués (1993 [1977]) e Wagley (1977 [1956]) e em outros contextos mais distantes no tempo e no espaço, como, por exemplo, nos estudos clássicos de Malinowiski (1976) e de Margareth Mead (1961 [1928]). No entanto, a análise do modo como as crianças trabalham exige a problematização de ser criança e de trabalhar em contextos específicos.

\subsection{O trabalho das crianças como apropriação de categorias do mundo adulto}

As crianças, principalmente os meninos, admiram certos trabalhos dos adultos e assim se apropriam de categorias do mundo adulto. Associamnos à coragem, à força física e à inteligência, e se sentem capazes de conhecê-los. Ser criança também evoca o desejo de tornar-se trabalhador

24 "A associação do trabalho com o mundo da ordem, tornando-o fonte de superioridade moral, leva também à valorização do trabalho dos filhos. Como o do homem e da mulher, o trabalho dos filhos faz parte do compromisso moral entre as pessoas na família" (SARTI, 1996, p. 103). 
Ser um trabalhador/tornar-se um abacataense: criança, socialização e aprendizagem em uma comunidade quilombola da Amazônia-PA

pelos atributos que identificam nos adultos trabalhadores, como discorreu Jacinto, seis anos:

Eu trabalho na roça, eu caço, eu pesco, tapo o rio. E sabe mais o que eu faço?! Eu laço boi, ando de cavalo, amarro a vaca, eu faço farinha, rapo macaxeira e tiro tucupi. E sabe mais? Eu uso terçado e faca amolada e pesco à noite sozinho, capino pra botar a roça, subo no açaizeiro para tirar açaí porque a minha mãe já tá muito velhinha e ela pode cair. E mais ainda: eu ando de bicicleta e de moto, vou lá em Ananindeua sozinho [no centro urbano] e já estou aprendendo a dirigir caminhão.

Com esses desejos, ou como imagina-se o adulto que se tornará, as crianças sempre se colocam como mais sabedoras no trabalho do que as avós e riem daquilo que elas não conseguem mais fazer, como disse Lesser: tapo rio e pesco com o meu pai [que é seu avô] e minha avó. Eu pesco melhor que a minha avó, enquanto eu pego só peixe grande, ela pega pouco peixe e só dos pequeno [junta os dedinhos indicadores, com um pequeno espaço entre eles, para mostrar o quanto o peixe pescado pela avó é insignificante], só pescadinha, por isso, eu ajudo ela [risos].

É possível observar que mesmo algumas práticas não sendo mais tão frequentes entre seus familiares, as crianças demonstram dominar certos conhecimentos relativos à geografia do lugar, como também às técnicas de pesca, de caça, de plantio, de colheita, de coleta, de criação e domesticação de animais, de manipulação de remédios disponíveis na natureza e com recomendação à cura de doenças, de confecção de instrumentos de caça, de um modo de feitura de um alimento, entre outros. São conhecimentos que se fazem presentes na vivência das crianças. As idas à mata, com elas, eram permeadas por muitas explicações. Nesses momentos, mostravam o rio, explicavam seus períodos de "cheia" e de "seca", os tipos de peixes que pescam nele, de quê e como faziam as iscas, os instrumentos de pesca, sua profundeza e os perigos conhecidos por todos.

As crianças (mais as meninas) aprendem a manipular os alimentos a partir dos oito anos de idade, começando com preparos simples, como 
cozinhar arroz. Com a idade de doze anos já preparam feijão, carnes cozidas e assam peixes. As crianças, desde os três anos aprendem a lidar com os animais de criação e de estimação por meio das brincadeiras com eles. São uma espécie de brinquedo para elas, principalmente os gatos que, na maioria das vezes, chegam às casas pelas mãos delas. Os adultos, mesmo contra a vontade de alguns, acabam cedendo à insistência dos pequenos para convencê-los a ficar com esses animais. É comum encontrálos em cima de camas, mesas, cadeiras e nos braços da pequenada.

O menino que cria galinhas, por diversas vezes comentou sobre os investimentos que fez para conseguir montar sua produção, contrariando a vontade da mãe:

Aprendi com a vovó a criar galinha, eu via ela fazendo e ia me dizendo, aí, eu ia fazendo com as galinha dela, aí, o meu primo ganhou um galo dela, eu emprestei dele $e$ comecei a criar as minhas. Agora, tenho quase umas trinta. Vendo os ovos, outros ponho pra chocar e as galinhas também dou pra mamãe vender, mas o papai compra de mim e não me paga [risos]. Gosto de ver elas crescendo e ficando gorda, bonita [risos]. Comecei da minha vontade, eu gosto, mas tem muita coisa que precisa saber, como o tempo certo da galinha chocar, o cuidado com os bicho que atacam elas, os ovos que são bom pra chocar, e tem a lua que não presta fazer isso, que é na lua minguante, parece. A vovó diz isso, não vinga.

Coletar frutos é um dos trabalhos que as crianças mais gostam de fazer e, de preferência, em grupo. Nesses momentos as crianças compartilham conhecimentos em processo de transferência de saber intrageracional, como comentou Lupino, nove anos: quando a gente vai junto é melhor, dois sobe e joga, um fica embaixo monteando, depois tira as podre, que o bicho comeu, aí, divide certinho, tudo igual. Os produtos das coletas, aquilo que sobra das partilhas, sempre são levados para suas casas, são consumidos, trocados, ou presenteados. É uma prática de crianças e adultos. A entrada cotidiana na mata faz com que as crianças se apropriem e desenvolvam conhecimentos acerca de seus recursos e das técnicas de uso. 
Ser um trabalhador/tornar-se um abacataense: criança, socialização e aprendizagem em uma comunidade quilombola da Amazônia-PA

As meninas também relatam suas aventuras com a pesca. Babiana, sete anos, mencionou as investidas: É difícil pegar tucunaré. Um dia um rumbou a rede, aí, esbandalhou a rede. Angélica, de sete anos complementa: $A$ gente pesca com a mamãe, ela traz a gente, às vez a gente só fica brincando. Érika, oito anos, cita os peixes que costumam pescar e os instrumentos que utilizam: A gente pega todo tipo de peixe com anzol e rede: cará, traíra, tilápia, e tucunaré. A gente faz isca de peixe pequeno e de camarão. Babiana observava: é bom pescar com 'colher de pau', é uma fruta que a gente faz isca pra pegar tilápia.

É possível dizer, portanto, que o trabalho das crianças, como apropriação de categorias do mundo adulto, insere o papel desempenhado pela transferência do saber agrário, agronômico, telúrico, ético, do saber prático, transmitido de mães/pais (e quem mais participe desse processo) para filhas e filhos. Sendo, pois, revelador do modo como sujeitos particulares vivenciam a "experiência individual e ordem cultural", no sentido de distinguir os valores dos fenômenos culturais em campos sociais de seus valores (SAHLINS, 1990).

As situações de transferência e entendimento de formas de saber, em processos educativos intergeracionais (verticais) e geracionais (horizontais) são mobilizadas entre crianças e adultos. Situações que também foram fundamentais para a compreensão de como as crianças chegam a ser o que são. A transferência de entendimentos e de formas de saber, neste caso, está sendo considerada, segundo Iturra (2002, p. 145), como parte central de um conceito de saber, ou epistemologia, pautado na capacidade do ser humano de entender e distinguir de forma ordenada, a partir das constatações externas e de forma argumentativa, de provar a partir de denominada substância ou especificidade do fato, a sua origem, a sua espécie e o seu destino.

\subsection{Brincar e trabalhar, brincar de trabalhar}

"Brincar e trabalhar" e "brincar de trabalhar" são duas atividades, ou conjunto de atividades, integrantes da vida diária das crianças. São tempos e espaços propícios ao desenvolvimento das técnicas de corpo ali valorizadas. Nas brincadeiras das crianças, as situações de trabalho dos abacataenses estão sempre presentes. É comum as meninas montarem brincadeiras de "casinha" nos quintais e dentro de suas casas. Outras brincadeiras são expressivas do trabalho de coleta: subir em árvores para coletar é a brincadeira preferida de meninos e meninas, mas a brincadeira 
de caçar é mais apreciada pelos meninos. É um momento onde exibem suas espertezas.

A compreensão da singularidade desses momentos, constituiu-se, especialmente para a primeira autora deste trabalho, em um exercício constante de compreensão da vida cotidiana da infância abacataense (animando a discussão com a segunda), onde "brincar e trabalhar" e "brincar de trabalhar" são parte da vida diária, como expressaram as escritas das crianças em seus diários ${ }^{25}$ :

Eu brinquei de pira-mãe. Eu brinquei de bola. Eu vou pra festa. Eu escutei música. Eu fiz farinha. Eu brinquei muito. Eu fiquei em casa e brinquei de pira-americana. Eu só fiz isso hoje. Fim (Domingo, 22/09/2011, Diário do Jasmim, 8 anos).

Hoje eu fui pro garapé duas vezes. Quando eu vim de lá, fui pra festa. Quando eu cheguei em casa, jantei e depois eu dormi. Quando foi de manhã, eu ajuntei o lixo. Depois, quando foi 11:30, eu entrei na escola. Quando nós saímo da escola, eu e os meus amigos da escola, eu fui direto pro jambeiro. Fim (Quarta-feira, 26/09/2011, Diário do Jasmim, 8 anos). Hoje eu acordei, tomei meu café, depois escovei meus dente e cuidei das minhas coisas e tomei meu banho, para ir pro colégio. Cheguei do colégio, eu fui andar de bicicleta, depois eu vi 'rebelde' e dormi e sonhei com os anjos (Quarta-feira, 22/08/2012, Diário da Rosa, 8 anos).

Hoje eu acordei e tomei o meu café e fiz as minhas coisas. Fui para o garapé com a minha irmã e de noite assisti jornal e filme e depois eu dormi e me acordei de madrugada pra beber café com bolo e

\footnotetext{
25 Algumas palavras as crianças escreveram como pronunciam e outras foram escritas com a ajuda das crianças maiores e de séries mais avançadas na escola.
} 
Ser um trabalhador/tornar-se um abacataense: criança, socialização e aprendizagem em uma comunidade quilombola da Amazônia-PA

dormi de novo. Esperei amanhecer. Então foi isso! (Quarta-feira, 29/07/2011, Diário da Lavanda, 10 anos, * período de férias escolares).

Quando eu chego da escola eu almoço e vou brincar, depois vou cuidar das minhas coisas. Eu vou tomar banho para entrar, eu vejo a novela (Terça-feira, Iris, 9 anos, Diário da Iris, 30/08/2011).

Esse era o cotidiano que estava presente na memória das crianças: expressivo de obrigações com a família, com a organização da vida doméstica e escolar; de cuidados com o outro e consigo; e, de espaços e tempos possibilitados às brincadeiras, ao encontro com seus pares. Contudo, essa distribuição de tarefas obrigatórias, entre adultos e crianças, crianças maiores e menores, pautava-se pela hierarquização e que não deixava de desencadear conflitos. O brincar, portanto, é tão importante como são tantos outros momentos para que uma criança se desenvolva, torne-se, isto é, construa subjetividade, porque, para isso, precisa, como qualquer um de nós, da intersubjetividade, como discute Toren (2010). Assim sendo, os seus brinquedos e as brincadeiras documentam o modo como os adultos se colocam perante as crianças e como esperam que se tornem.

Por fim, e por enquanto, queremos dizer que o recorte teóricometodológico possibilitou inferir que a socialização e o aprendizado no e para o trabalho, ou de como tornar-se um abacataense, é parte da organização social de Abacatal e um processo de aprendizagem ao longo da e para a vida. O que não significa, consequentemente, como mostrado ao longo deste texto, tornar-se ou ser, como criança, uma trabalhadora/um trabalhador rural, uma camponesa/um camponês ou agricultora/agricultor familiar, mas alguém que carrega na base de sua formação conhecimentos da lida com a terra e do trabalho doméstico e comunitário - o "aprendizado da vida", afinal - que, no caso de Abacatal, concerne, ainda, à aquisição de uma consciência política na luta pelo território quilombola.

\section{Referências bibliográficas}


ACEVEDO, R. M.; CASTRO, E. No caminho de pedras do Abacatal: experiência social de grupos negros no Pará. Belém: NAEA/UFPA, 2004.

BOURDIEU, Pierre. Esboço de uma teoria da prática. Portugal: Celta Editora. 2002.

BRANDÃO. Carlos Rodrigues. O que é Educação. Coleção Primeiros Passos. São Paulo: Brasiliense. 1981.

CARDOSO DE OLIVEIRA, Roberto. O Eu, suas identidades e o mundo moral. Anuário Antropológico, Rio de Janeiro, 2002.

CARDOSO DE OLIVEIRA Luís Roberto. Honra, Dignidade e Reciprocidade. Série Antropologia, 344. Brasília, 2004

CARNEIRO, Maria José. Do "Rural" como categoria de pensamento e como categoria analítica. In: CARNEIRO, Maria José (Org.). Ruralidades Contemporâneas: modos de viver e pensar o rural na sociedade brasileira. Rio de Janeiro: Maumad X: FAPERJ, 2012.

CERTAU, Michel de. A Invenção do Cotidiano. Petrópolis, RJ: Vozes, 2012. COHN, Clarice. Antropologia da criança. Rio de Janeiro: Jorge Zahar, 2005. A Experiência da infância e o aprendizado entre os Xikrin. In: SILVA, Aracy Lopes da \& NUNES, Angela. Contribuições da etnologia indígena brasileira à antropologia da criança. In: Crianças Indígenas Ensaios Antropológicos. São Paulo: Global Editora, 2002.

COSTA, Dora Henrique \& CALVÃO, Léa. Trabalho Infantil. In: FRIGOTTO, Galdêncio \& CIAVATTA, Maria. A experiência do trabalho e a educação básica. Rio de Janeiro: Lamparina, 201

EVANS-PRITCHARD, E.E. Os Nuer: uma descrição do modo de subsistência e das instituições políticas de um povo nilota. São Paulo: Perspectiva, 2011.

FIRTH, Raymond. Elementos de organização social. Rio de Janeiro: Zahar, 1974.

FONSECA, Claudia. Caminhos da adoção. São Paulo: Cortez, 1995.

GARCIA Jr., Afrânio Raul Garcia. Terra de trabalho: trabalho familiar de pequenos produtores. Rio de Janeiro: Paz e Terra, 1983.

GREGORI, Maria Filomena. Viração. São Paulo: Companhia das Letras, 2000.

ITURRA, Raúl. A epistemologia da infância: ensaio de antropologia da educação. Educação, Sociedade \& Cultura. Universidade do Porto. Vol. 17, 2002, p. 135-153. 
Ser um trabalhador/tornar-se um abacataense: criança, socialização e aprendizagem em uma comunidade quilombola da Amazônia-PA

O processo educativo: ensino ou aprendizagem. Educação, Sociedade \& Cultura. Universidade do Porto. Vol. 1, 1994

JAMES, A. \& PROUT, A. Re-Presenting Childhood: Time and Transition in the Study of Childhood. In: JAMES A. \& PROUT, A. Constructing and Reconstructing Childhood. Basingstoke: Falmer Press, 1990.

LAGO, Syane de Paula da Costa. Namoro pra casar? Namoro pra escolher (com quem casar): idéias e práticas de namoro entre jovens em Belém/PA. 2002. 122 f. Dissertação (Mestrado) - Curso de Mestrado em Antropologia, Centro de Filosofia e Ciências Humanas, Universidade Federal do Pará, Belém

LÉVINAS, Emmanuel. Entre Nós: ensaios sobre a alteridade. Petrópolis-RJ: Vozes, 2010.

MALINOWSKI, B. Argonautas do pacífico ocidental. São Paulo: Abril Cultural, 1976.

MAUSS, M. Sociologia e Antropologia. São Paulo: Cortez, 2003.

MEAD, Margaret. Coming of age in Samoa. PAIDOS: Barcelona, 1961

MENDONÇA, Kátia. Valores para a Paz. Belém: UFPA, 2013.

MOTTA-MAUÉS, Maria Angelica . $\mathrm{Na}$ "casa da mãe"/na "casa do pai": Anotações (de uma antropóloga e avó) em torno da "circulação" de crianças. REVISTA DE ANTROPOLOGIA, SÃO PAULO, USP, 2004, V. 47 № 2 .

"Trabalhadeiras" \& "Camarados": relações de gênero, simbolismo e ritualização numa comunidade amazônica. Belém: IFCH/UFPA, 1993.

Uma vez "cria" sempre "cria" (?): adoção, gênero e geração na

Amazonia. In: Nortes Antropológicos: trajetos, trajetórias. LEITÃO, Wilma M \& MAUÉS, Heraldo (Orgs.). Belém: EDUFPA, 2008.

Uma mãe leva a outra. Práticas informais (mas nem tanto) de "circulação de crianças" na Amazonia. Scripta Nova. Revista Eletrónica de Geografia y Ciencias Sociales, Barcelona, Vol. 16 (2012) .

NUNES, Angela. "Brincando de ser criança": contribuições da etnologia indígena brasileira à antropologia da infância. Tese de doutoramento, Departamento de Antropologia, ISCTE, Lisboa, Portugal, 2003.

PIRES, Flávia Ferreira. Quem tem medo do mal-assombro?: religião e infância no semiárido nordestino. Rio de Janeiro: E-papers; João Pessoa: UFPB, 2011.

$O$ que as crianças podem fazer pela antropologia? Horizontes. Antropológicos. [online]. 2010, vol.16, n.34, pp. 137-157. ISSN 0104-7183. 
Pesquisando crianças e infância: abordagens teóricas para o estudo das (e com as) crianças. Cadernos de campo, São Paulo, n. 17, p. 1-348, 2008.

PANTOJA, Ana Lídia Nauar. Sendo mãe, sendo pai: sexualidade, reprodução e afetividade entre adolescentes de grupos populares em Belém /Tese (Doutorado) Universidade Federal do Pará, Instituto de Filosofia e Ciências Humanas, Programa de Pós-Graduação em Ciências Sociais, Belém, 2007.

PANTOJA, Mariana Ciavatta. Os Milton: cem anos de história nos seringais. Recife: Fundação Joaquim Nabuco, Editora Massangana, 2004.

PRIORE, Mary Del. Ao Sul do Corpo: condição feminina, maternidades e mentalidades no Brasil Colônia. Rio de Janeiro: José Olympio-DF: Edunb, 1993

QVORTRUP, Jeans. A volta do papel das crianças no contrato geracional. Rev. Bras. Educ.[online]. v.16, n.47, p. 323-332. 2011.

SAHLINS, Marschall. Metáforas históricas e realidades míticas: Estrutura nos primórdios da história do reino das ilhas Sandwich. Rio de Janeiro: Zahar, 2008. Ilhas de História. Rio de Janeiro: Zahar, 1990.

SARTI, Cyntia Andersen. A família como espelho: um estudo sobre a moral dos pobres. São Paulo: Autores Associados, 1996.

SCHNEIDER, Sérgio. Agricultura e trabalho infantil: uma apreciação crítica do estudo da OIT. Porto Alegre: Instituto de Formação Sindical Irmão Miguel, Série Documentos, 1, 2005.

SILVA, Aracy Lopes da \& NUNES, Angela. Contribuições da etnologia indígena brasileira à antropologia da criança. In: Crianças Indígenas Ensaios Antropológicos. São Paulo: Global Editora, 2002.

STROPASOLAS, Valmir Luis. Trabalho Infantil no Campo: do problema social ao objeto sociológico. Revista Latino-americana de Estudos do Trabalho, Ano 17, no 27, 2012, 249-286.

TOREN, Christina. Making History: the significance of childhood cognition for a comparative anthropolology of mind. 1993.

Como sabemos o que é verdade? O caso do Mana em Fiji. Revista Mana, 2006, p. 449-477.

A matéria da imaginação: o que podemos aprender com as idéias das crianças fijianas sobre suas verdades como adultos. Horizontes Antropológicos. Porto Alegre, ano 16, n 34, p. 19-48, jul./dez. 2010.

"Comparison and ontogeny". In: (ed. Gingrich, A. e Fox, R.) Antropology by comparison: Routledg, 2002. 
Ser um trabalhador/tornar-se um abacataense: criança, socialização e aprendizagem em uma comunidade quilombola da Amazônia-PA

Becoming a Christian in Fiji: an ethnographic study of ontogeny. Royal Anthropological Institute. Journal of the Royal Anthropological Institute. (N.S.) 10,221-240. Londres, 2004

VELHO, Gilberto. Família e Subjetividade. In: Pensando a Família no Brasil. ALMEIDA, Ângela Mendes de (Org.).Rio de Janeiro: Espaço e Tempo, 1987. WAGLEY, Charles. Uma comunidade amazônica. São Paulo: Companhia Editora Nacional; Brasília: INL, 1977.

WOORTMANN, F. Hellen. A árvore da memória. Série Antropologia. Brasília, 1994.

WOORTMANN, Klaas. "Com parente não se neguceia": o campesinato como ordem moral. Anuário Antropológico/87. Editora Universidade de Brasflia/Tempo Brasileiro, 1990. 